\title{
CONGENITAL MITRAL VALVE DYSPLASIA IN A FEMALE CHILD: INFECTIVE ENDOCARDITIS OR HERITABLE DISORDER OF CONNECTIVE TISSUE?
}

\author{
Jelena M. Nestorovic-Tanaskovic1, Aleksandra M. Simovic1, Milan Djukic², Jasmina B. Knezevic1, Zoran R. Igrutinovic ${ }^{\text {, }}$ \\ Zorica D. Raskovic \\ ${ }^{1}$ Pediatric Clinic, Clinical Centre "Kragujevac", Faculty of Medical Sciences, University of Kragujevac, Kragujevac, Serbia
}

2University Children's Hospital, Faculty of Medicine, University of Belgrade, Belgrade, Serbia

\section{KONGENITALNA DISPLAZIJA MITRALNE VALVULE U ŽENSKOG DETETA: INFEKTIVNI ENDOKARDITIS ILI NASLEDNI POREMEĆAJ VEZIVNOG TKIVA?}

\author{
Jelena M. Nestorović-Tanaskovićl, Aleksandra M. Simovićl, Milan Đukić2, Jasmina B. Kneževićl, Zoran R. Igrutinovićl, \\ Zorica D. Raškovićl \\ ${ }^{1}$ Klinika za pedijatriju, Klinički centar „,Kragujevac“, Fakultet medicinskih nauka, Univerzitet u Kragujevcu, Kragujevac \\ 2Univerzitetska dečja klinika, Medicinski fakultet Univerziteta u Beogradu, Beograd
}

\section{ABSTRACT}

Introduction. Dysplastic or myxomatous mitral valve is characterized by myxomatous degeneration of collagen and elastin which causes excess growth of mitral valves. In due course, some pathological characteristics may develop, such as mitral valves prolapse with considerable regurgitation, while surface abnormalities of such valves might predispose thromboembolic complications or infective endocarditis.

Case report. Three years and seven months old female child was suspected of having infective endocarditis based on the medical history, clinical signs and performed investigations. According to the Duke criteria, she had: 1 major sign - positive echocardiographic finding on the heart (existence of "verrucae" on mitral valve apparatus) and 3 minor signs - prolonged fever, one positive blood culture and arthralgia. After the applied antibiotic therapy, the control echocardiographic finding was unchanged, laboratory analyses were within normal range and the general condition of the child was good. Therefore, we considered it as myxomatous degeneration of mitral valve apparatus which is very similar to verrucous changes.

Conclusion. Based on similar phenotype and echocardiographic characteristics of the little girl and her father we believe that the case in question was congenital mitral valve dysplasia with possible heritable disorder of connective tissue.

Key words: heart diseases; congenital abnormalities; child, preschool.

\section{INTRODUCTION}

The multitude of names for mitral valve disorders - the floppy mitral valve (FMV), mitral valve prolapse (MVP), or mitral valvular regurgitation (MVR) - and the variability of diagnostic criteria related to children have emerged (1-6). The fusion of FMV/MVP/MVR dates back to the 1960 s (2). Prevalence of FMV/MVP is about $1-5 \%$

\section{SAŽETAK}

Uvod. Displastičnu ili miksomatoznu mitralnu valvulu karakteriše miksomatozna degeneracija kolagena i elastina, koja dovodi do bujanja mitralnih zalistaka. Vremenom mogu da se razviju patološke karakrteristike, kao što je prolaps valvula sa značajnom regurgitacijom, a površinske abnormalnosti takvih zalistaka mogu da predisponiraju tromboembolijske komplikacije ili infektivni endokarditis.

Prikaz bolesnika. Kod devojčice uzrasta 3 godine $i 7$ meseci na osnovu anamneze, kliničke slike $i$ učinjenih ispitivanja postavljena je ozbiljna sumnja na infektivni endokarditis. Ispunjavala je, prema Dukeovim kriterijumima, 1 major - pozitivan ehokardiografski nalaz na srcu (prisustvo ,veruke“ na mitralnom aparatu) i 3 minor znaka - prolongirana febrilnost praćena groznicom, pozitivna jedna hemokultura $i$ artralgije. Posle primene antibiotske terapije, kontrolni ehokardiagrafski nalaz bio je nepromenjen, laboratorijske analize u granicama normale, opšte stanje deteta dobro. Zato smo uzeli u razmatranje da je reč o miksomatoznoj degeneraciji mitralnog aparata, koja veoma podseća na verukozne promene.

Zaključak. Na osnovu sličnih fenotipskih $i$ ehokardiografskih karakteristika devojčice $i$ njenog oca, mislimo da je reč o kongenitalnoj displaziji mitralne valvule s mogućim naslednim poremećajem vezivnog tkiva.

Ključne reči: bolesti srca; kongenitalne anomalije; dete, predškolsko.

and it increases with age $(1,2)$. Three autosomal dominant and one X-linked genetic loci for FMV/MVP have been found over the last few years $(2,7-10)$.

The basis for diagnosis is $(1,2,6)$ : a history or detailed family history of the development of connective tissue or MV disorders; general inspection, anthropometrics (a patient may have asthenia, hypomastia or skeletal abnormalities: pectus excavatum/carinatum, scoliosis, straight back, marfanoid appearance); symptoms 
(palpitations, fatigue, exercise intolerance, dyspnea, chest pain, postural phenomena, syncope/presyncope, neuroendocrine or autonomic dysfunction); auscultation (the mid-systolic click accompanying a systolic murmur, mild or progressive MV regurgitation); electrocardiogram (the vast majority of patients have a normal resting electrocardiogram; ST and T-wave changes may improve with exercise); chest radiograph; echocardiography (it is a sensitive tool in the differentiation of degenerative MV disease); cardiac magnetic resonance.

Congenital MV dysplasia can become symptomatic at any age and may sometimes require surgical treatment (3, 4,11 ). Clinical expression (phenotype) in FMV/MVP may vary among family members with heritable connective tissue disorders (Marfan syndrome, Stickler syndrome, Ehlers-Danlos syndrome types I, II or IV, Osteogenesis imperfecta syndromes, Fragile X syndrome- Martin-Bell syndrome, Polycystic kidney disease in adults, Pseudoxanthoma elasticum etc.) posing additional diagnostic challenges (10-14).

Possible complications are MR progression, atrial or ventricular arrhythmias, congestive heart failure, infective endocarditis, embolic phenomena or sudden death $(1,2)$.

\section{THE CASE}

Three years and seven months old female child weighing $14.4 \mathrm{~kg}$, body height $98.9 \mathrm{~cm}$ was referred to our clinic with clinical signs of upper respiratory tract infections (sore throat and lower legs, nasal secretion, fever up to $39.9^{\circ} \mathrm{C}$ ). During the previous month the child had suffered from frequent respiratory infections. Complete biochemical analyses were within normal ranges except for slightly elevated erythrocyte sedimentation (SE $35 \mathrm{~mm} / \mathrm{h}$, repeated was $5 \mathrm{~mm} / \mathrm{h}$ ), and leukocytosis $12.2 \times 109 / \mathrm{L}$ (neutrophils $85 \%$ ), repeated was $7.4 \times 109 / \mathrm{L}$.

She has systolic murmur, the intensity 2-3/6 left parasternal and at the apex. Electrocardiogram and chest radiograph were normal. Echocardiography was performed (29/09/2011, Figures 1 and 2). Because of the suspected infective endocarditis, 5 blood cultures were taken. In the second one, Staphylococcus haemolyticus was isolated.

Echocardiographic examination (13/10/2011) showed that both mitral leaflets significantly protruded into the left atrium during systole, with MR grade $+1.5 / 4$. The anterior

Figures 1 and 2. Two dimensional echocardiography-left parasternal four-chamber view, showing mitral valve leaflets with spherical apical thickening diameter around 8-10 mm, inhomogeneous structure, (central hypoechogenic).
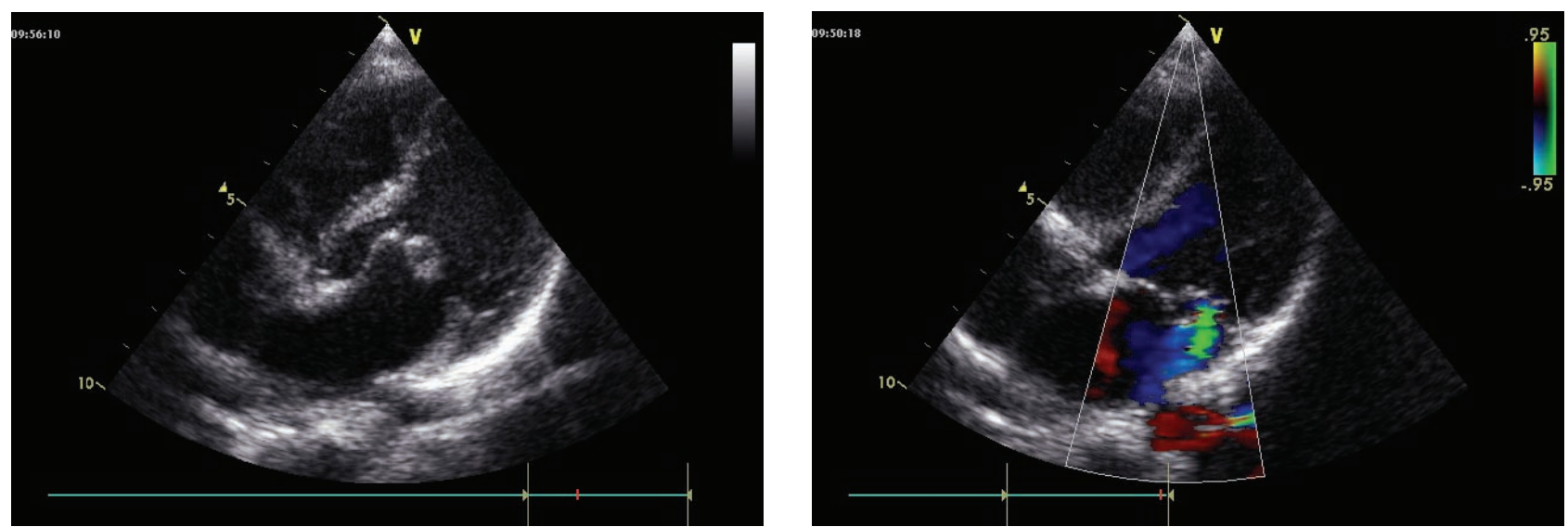

Figures 3 and 4. Two dimensional echocardiography-long axis view, showing altered morphology of both leaflets, especially anterior mitral valve leaflet with systolic regurgitate jet semi- quantified as $+1-1.5 / 4$
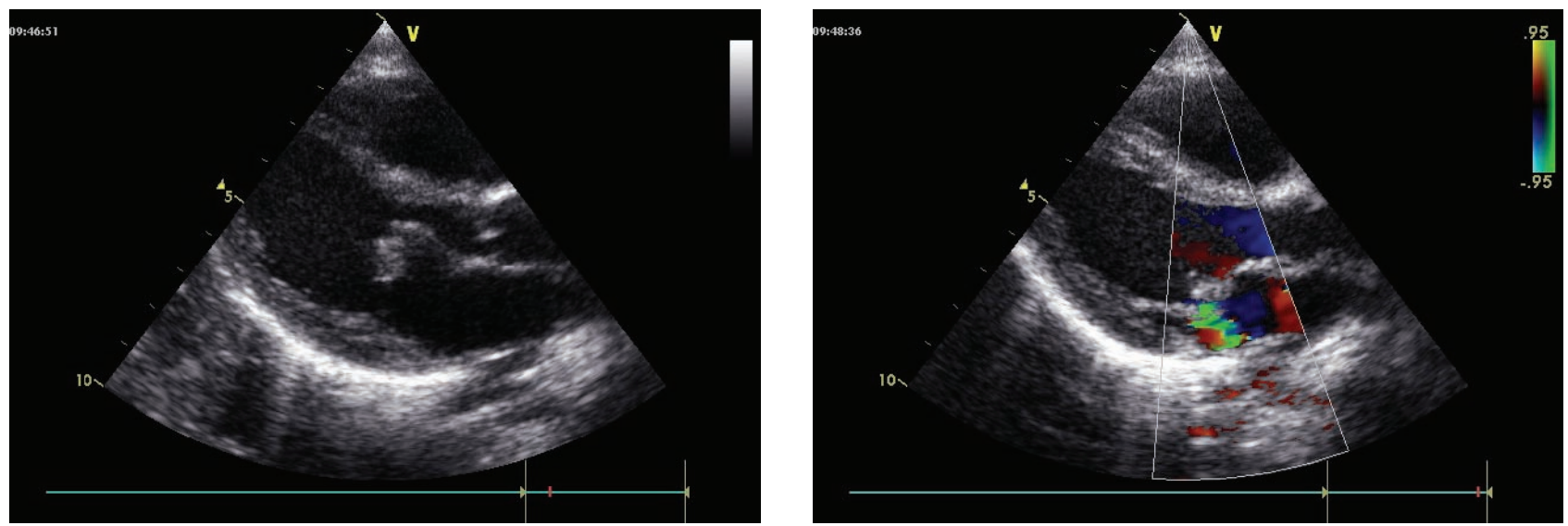
mitral leaflet was dysplastic with registered suspected verrucous formations of $8 \times 4-5 \mathrm{~mm}$ diameter. The left ventricle was circular in cross-section and of good global contractility: end-diastolic diameter (EDD) was $32 \mathrm{~mm}$, end-systolic diameter (ESD) was $20 \mathrm{~mm}$ and ejection fraction (EF) was 70\%, fractional shortening (FS) was $38 \%$. Left atrial (LA) was $17 \mathrm{~mm}$; aorta (Ao) was $13 \mathrm{~mm}$. Repeated complete biochemical analysis (parameters of inflammation) and five blood cultures (sterile) were within normal limits.

Control echocardiography was performed (7/12/2011): altered morphology of both MV leaflets, especially the anterior one. In the left ventricle (LV) there were two papillary muscles, degenerative leaflet by normally developed chordae tendineae. Posterior MV was normal appearance and movement. Anterior cusp was very elongated with spherical apical thickening of about $9 \mathrm{~mm}$ diameter (inhomogeneous structure with central hypoechogenic zone) which was not supportive of bacterial verrucae; there was also no typical flotation. Doppler on the MV recorded systolic regurgitate jet semi quantified as $+1-1.5 / 4$ directed to the left and rear. (EDD $34 \mathrm{~mm}$, EDS $22 \mathrm{~mm}$, FS 35\%). Other findings were normal. Echocardiography, which was made on 14/03/2012 (6 months after the initial ultrasound examination of the heart), was identical to the first one (Figures 3 and 4).

\section{DISCUSSION}

The aim of this paper is to review our experience with a rare form of MV dysplasia. Three years and seven months old female child was strongly suspected of having infective endocarditis (15) according to differential diagnostic procedure based on clinical signs (sore throat and sore lower legs in the evening, long-lasting fever with pauses in the period of one and a half months, one positive blood culture, first time detected heart murmur projected by the mitral valve apparatus and echocardiographic finding - suspected verrucae on mitral valves). According to the Duke criteria, the patient met 1 major criterion (positive ultrasound finding on the heart - existence of verrucae on mitral valve apparatus) and 3 minor criteria: high temperature - fever, one positive blood culture and arthralgia) (15). These criteria were not sufficient for diagnosis of infective endocarditis. Patient had myxomatous changes on mitral valve apparatus which looked a lot like verrucous changes according to the echocardiographic finding.

Myxomatous degeneration is inherited as autosomal dominant $(1,2,8,9)$, and since the girl's father had been diagnosed with myxomatous changes of mitral valve apparatus, this was then more supportive of myxomatous changes of mitral valve. Also, the girl had large ocular bulbs, small chin, thin nasal pyramid, thin skin with visible veins, especially on the chest, pectus excavatum, bruises on the legs, cutis laxa, hyper-elastic joints, possible exostoses. Therefore, we think that the described change on mitral valve was only a part of the broader clinical condition belonging to the group of connective tissue diseases (1, 2, 13-15).

Father had a chest deformity, skin hyper-elasticity of smaller extent (most prominent on abdomen) and thinner skin, especially on the feet. Based on the medical history, clinical signs, phenotype characteristics and performed investigations, the Ehlers-Danlos syndrome was suspected. According to differential diagnostic procedure some other connective tissue diseases might be considered as well $(1,2,13-15)$, such as Cutis laxa, Marfan syndrome and homocystinuria. Molecular genetic analyses of isolated DNA or skin fibroblast $(1,2)$ are performed for some forms, which was not done here due to technical and financial reasons (such analyses are not performed in Serbia).

Three years and seven months old girl with dysplasia of both mitral leaflets (particularly anterior one) with MR graduate 1,5/4 was strongly suspected of having infective endocarditis according to differential diagnostic procedure. According to the Duke criteria, the patient met 1 major criterion (positive ultrasound finding on the heart - existence of verrucae on mitral valve apparatus) and 3 minor criteria: high temperature - fever, one positive blood culture and arthralgia. Based on phenotype characteristics of the little girl and her father, repeated echocardiographic finding (apical thickening of front mitral cusp is of inhomogeneous structure and without characteristic flotation) and good general condition of the child during hospitalization, the case was most probably the congenital mitral valve dysplasia within broader clinical condition belonging to the group of heritable connective tissue diseases. This was supported by the fact that the results of repeated echocardiographic examination remained unchanged 6 months after the first examination.

\section{REFERENCES}

1. Charitakis K, Basson CT. Degenerating heart valves: fill them up with filamin? Circulation 2007; 115: 2-4.

2. Boudoulas $H$. The floppy mitral valve, mitral valve prolapse, mitral valvular regurgitation and the floppy mitral valve/mitral valve prolapse syndrome. Current concepts. Hellenic J Cardiol 2004; 45: 339-44.

3. Nasuti JF, Zhang PJ, Feldman MD, et al. Fibrillin and other matrix proteins in mitral valve prolapse syndrome. Ann Thorac Surg 2004; 77: 532-6.

4. Barth PJ, Koster H, Moosdorf R. CD34+ fibrocytes in normal mitral valves and myxomatous mitral valve degeneration. Pathol Res Pract 2005; 201: 301-4. 
5. Van Der Ham DP, De Vries JK, Van Der Merwe PL. Mitral valve prolapse: A study of 45 children. Cardiovasc J S Afr 2003; 14: 191-4.

6. Nesta F, Leyne M, Yosefy C, et al. New Locus for autosomal dominant mitral valve prolapse on chromosome 13: clinical insights from genetic studies. Circulation 2005; 112: 2022-30.

7. Roberts R. Another chromosomal locus for mitral valve prolapse. Close, but no cigar. Circulation 2005; 112: 1924-6.

8. Beierlein W, Becker V, Yates R, et al. Long-term follow-up after mitral valve replacement in childhood: poor event-free survival in the young child. Eur J Cardiothorac Surg 2007; 31: 860-5.

9. Adams DH, Anyanwu AC, Rahmanian PB, Abascal V, Salzberg SP, Filsoufi F. Large annuloplasty rings facilitate mitral valve repair in Barlow's disease. Ann Thorac Surg 2006; 82: 2096-100.

10. Ng CM, Cheng A, Myers LA, et al. TGF-b- dependent pathogenesis of mitral valve prolapse in a mouse model of Marfan syndrome. J Clin Invest 2004; 114: 1586-92.
11. Richards AJ, Laidlaw M, Whittaker J, et al. High efficiency of mutation detection in type 1 Stickler syndrome using a two-stage approach: vitreoretinal assessment coupled with exon sequencing for screening COL2A1. Hum Mutat 2006; 7: 696-704.

12. Richards AJ, Meredith S, Poulson A, et al. A novel mutation of COL2A1 resulting in dominantly inherited rhegmatogenous retinal detachment. Invest Ophthalmol Vis Sci 2005; 46: 663-8.

13. Adams DH, Anyanwu AC. The cardiologist's role in increasing the rate of mitral valve repair in degenerative disease. Curr Opin Cardiol 2008; 23: 105-10.

14. Karkow D. Heritable diseases of connective tissue. In: Firestein GS, Budd RC, Gabriel SE, et al., eds. Kelley`s Textbook of Rheumatology. 9th ed. Philadelphia: Elsevier Saunders, 2012: 105.

15. Bernstein D. Infective endocarditis. In: Kliegman R, Stanton B, Geme SJ, Scor N, Behrman R, eds. Nelson Textbook of Pediatrics. 19th ed. Philadelphia: Saunders, 2011; 1565-9. 